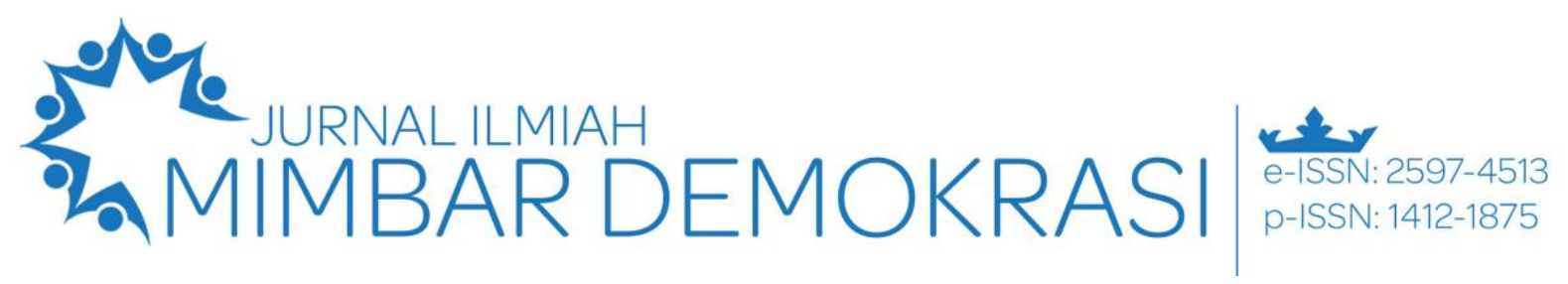

Vol. 19 No. 2 Tahun $2020 \mid$ Hal. $32-39$

\title{
Internalisasi Nilai-Nilai Pancasila dalam Mencegah Paham Radikal
}

\author{
Sri Rahayu Pudjiastuti a, 1* \\ a Pasca Sarjana STKIP Arrahmaniyah Depok, Indonesia \\ 1 yayu.pudjiastuti@gmail.com \\ *Korespondensi penulis
}

\section{Diterima:}

Informasi artikel

28-03-2020

Disetujui:

10-04-2020

Kata kunci:

Internalisasi

Nilai-nilai Pancasila

Paham Radikal

\section{Keywords:}

Internalisation

Pancasila Values

Radical

Understanding

\begin{abstract}
ABSTRAK
Penelitian deskriptif ini bertujuan untuk memberi kontribusi pemikiran, gagasan dan strategi dan upaya dalam melakukan internalisasi nilai-nilai Pancasila untuk mencegah perkembangan paham radikal. Penulisan ini menggunakan metode deskriptif yang dilihat secara komprehensif integral. Hasil penelitian ini menjelaskan bahwa; kondisi internalisasi nilai-nilai Pancasila saat ini adalah; lemahnya sistem pendidikan, resistensi terhadap ideologi Pancasila, kurangnya keteladanan pemimpin, dan meningkatnya pengaruh negatif dari nilai-nilai yang tidak sesuai dengan Pancasila. Internalisasi nilai-nilai Pancasila dilakukan dengan cara; penguatan sistem pendidikan, peningkatan jati diri dan karakter bangsa, peningkatan komitmen pemimpin nasional, peningkatan pemahaman nilai-nilai Pancasila pada kehidupan sehari-hari untuk meningkatkan daya tangkal akan pengaruh negatif melalui pendidikan, sosialisasi dan kerjasama. Penelitian ini menyimpulkan bahwa internalisasi nilai-nilai Pancasila dapat meningkatkan kewaspadaan masyarakat dalam menangkal penyebaran paham-paham radikal.
\end{abstract}

\begin{abstract}
Pancasila Values Internalisation to Prevent Radical Ideology. This descriptive research aims to contribute thoughts, ideas and strategies and efforts to internalize the values of Pancasila to prevent the development of radical understanding. This writing uses a descriptive method that is seen as a comprehensive integral. The results showed that the current conditions of internalizing Pancasila values were; weak education system, resistance to the ideology of Pancasila, lack of exemplary leaders, and the increasing negative influence of external values that are not in accordance with Pancasila. The internalization of Pancasila values is done by; strengthening the education system, enhancing national identity and character, increasing the commitment of national leaders, increasing understanding of Pancasila values in daily life to increase the deterrence of negative influences through education, outreach and cooperation. This study concludes that the internalization of the values of Pancasila can increase community awareness in counteracting the spread of radical ideas.
\end{abstract}

Copyright (C) 2020 (Sri Rahayu Pudjiastuti). All Rights Reserved

How to Cite: Pudjiastuti, S. R. (2020). Internalisasi Nilai-Nilai Pancasila dalam Mencegah Paham Radikal. Jurnal Ilmiah Mimbar Demokrasi, 19(2), 32-39. DOI: 10.21009/jimd.v19i02.14788

This work is licensed under a Creative Commons Attribution-ShareAlike 4.0 International License. Allows readers to read, download, copy, distribute, print, search, or link to the full texts of its articles and allow readers to use them for any other lanful purpose. The journal hold the copyright. 


\section{Vol. 19 No. 2 Tahun 2020 | Hal. 32 - 39}

\section{Pendahuluan}

Persebaran paham radikal dan intoleran memang sudah marak terjadi di mana-mana, termasuk di Indonesia, hal ini dapat membahayakan, karenanya harus segera mengambil langkah untuk dapat menangkalnya. Menurut lembaga kajian Leimena Institute, bahwa paham radikal sudah masuk ke sekolahsekolah dan mempengaruhi siswa-siswa (BBC.com, 2017). Tidak terinternalisasinya pendidikan Pancasila, berdampak buruk pada pemahaman guru dan siswa mengenai bagaimana hidup dalam masyarakat yang multikultural. Kurikulum pendidikan Pancasila dan kewarganegaraan sangat minim dalam mengkaji multikulturalisme. Hal ini karena materi Pancasila tidak diinternalisasikan dalam kehidupan di sekolah, di rumah maupun di masyarakat (Napitupulu, 2017). Ancaman terhadap ideologi kebangsaan semakin nyata, hal ini diiringi dengan menguatnya kelompok radikal dan garis keras yang mulai menyebarkan pahampaham radikal untuk mempengaruhi masyarakat Indonesia di mana bertujuan untuk mengubah ideologi Pancasila menjadi ideologi lain. Apalagi terdapat partai politik yang merangkul dan bekerjasama dengan kelompok-kelompok garis keras tersebut (Suparman, 2017).

Menurut kepala BNPT, penyebaran paham radikal dan intoleran sudah terjadi secara sistematis. Paham ini diajarkan kepada anakanak dilembaga pendidikan dasar hingga perguruan tinggi (Suparman, 2017). Hal ini disebabkan karena rendahnya internalisasi nilainilai Pancasila kepada sekelompok masyarakat dan generasi muda (Sumardjoko, 2017). Banyak generasi muda kita yang mengabaikan isi Pancasila baik secara harfiah maupun maknawi. Fenomena lain yang menunjukkan telah bergesernya atau melemahnya ideologi Pancasila adalah dengan melihat dari banyaknya Peraturan Daerah (Perda) yang telah direvisi oleh Kementrian Dalam Negeri karena Perda ini tidak relevan dengan nilai-nilai Pancasila (Detik, 2015).

Banyak produk hukum dan tindakan penegakkan hukum yang kurang mencerminkan nilai-nilai Pancasila, yang tersirat dengan belum dirasakannya keadilan serta rendahnya nilai moral dan akhlak di masyarakat. Selain itu, kasus-kasus korupsi yang banyak menjerat para penyelenggara negara menjadi suatu contoh buruk yang dipertontonkan kepada masyarakat sehingga dapat melunturkan rasa cinta dan nasionalisme masyarakat kepada NKRI. Dari fenomena-fenomena berkembangnya paham radikal yang terjadi di ranah publik, menunjukkan akan semakin lemahnya internalisasi dari nilai-nilai Pancasila di dalam masyarakat maupun penyelenggara negara, khususnya pada nilai-nilai praksis Pancasila yang ditunjukkan dengan semakin memudarnya toleransi sosial dan seringnya terjadi konflik horizontal yang berdimensi keagamaan.

Dengan melihat fenomena dan fakta yang telah diuraikan, maka formulasi pokok masalah adalah internalisasi nilai-nilai Pancasila belum terselenggara dengan baik sehingga tidak dapat menangkal penyebaran paham radikal secara optimal. Untuk itu perlu dirumuskan konsepsi untuk lebih mengoptimalkan upaya internalisasi nilai-nilai Pancasila.

Menurut Kalidjernih (2010) internalisasi adalah penanaman perilaku, sikap dan nilai seseorang yang didapatnya dalam proses pembinaan, belajar dan bimbingan, di mana siswa yang belajar dapat diterima sebagai bagian, yang mengikat diri mereka dalam nilai dan norma yang berlaku dalam masyarakat Humannira, 2016).

John Finley Scott (1971) menyatakan bahwa internalisasi melibatkan suatu ide, konsep dan tindakan yang mengalir dalam pikiran kita dengan mengalami pergerakan dari luar menuju pikiran sebagai suatu kepribadian. Struktur dan kejadian dalam masyarakat lazim membentuk pribadi yang dalam dari seseorang sehingga terjadi internalisasi (Humannira, 2016). Hal ini berarti, internalisasi adalah proses yang dilakukan berkali-kali di dalam meniru tindakan seseorang, hingga akhirnya keadaan ini menjadi suatu pola yang mantap dan norma yang mengatur tindakannya dibudayakan, hingga nilai tersebut diyakini menjadi pandangan dan tindakan moral seseorang. Untuk meningkatkan pemahaman dan implementasi nilai-nilai Pancasila pada masyarakat, harus diiringi dengan upaya dari luar masyarakat yang dalam hal ini adalah pemerintah untuk menciptakan lingkungan pendidikan, keteladanan serta contoh perilaku yang mendukung dalam pengimplementasian nilai-nilai Pancasila sehingga nilai-nilai tersebut dapat dengan mudah terinternalisasi dalam diri masyarakat.

Dalam teori habitus dijelaskan bahwa, habitus adalah disposisi yang menjadi dasar kepribadian seseorang. Wujud disposisi bisa berupa sikap, kecenderungan dalam 
mempersepsi, merasakan, bertindak dan berpikir yang dibatinkan individu berkat kondisi obyektif keberadaan seseorang. Konsep habitus dalam revolusi mental bisa dilaksanakan bila masyarakat dengan kehendak kuat dan kebebasannya berjuang keluar dari determinisme mindset lama; mentalitas menerabas, kebiasaan korupsi, dan lemahnya etos kerja.

Teori Giddens (1989) menjelaskan bahwa dialektika hubungan antara agent dan struktur sosial merupakan habitus yang akan menerjemahkan arah orientasi sosial. Seperti hal nya perubahan habitus butuh modalitas dan sistem, demikian pula perubahan struktural menurut Giddens juga membutuhkan perubahan modalitas (kerangka penafsiran, fasilitas, norma). Dalam struktur sosial, terkandung aturan-aturan dan sumber daya atau seperangkat relasi transformatif, tindakan kolektif diorganisir sebagai bagian dari sistem sosial.

Penanaman nilai-nilai bila mau efektif harus memperhitungkan tiga prinsip terbentuknya karakter; pertama, karakter dibentuk oleh apa yang kita lakukan, bukan oleh yang kita katakan, ketahui atau yakini; kedua, setiap pilihan atau keputusan membantu mengarahkan akan menjadi orang semacam apa; ketiga, karakter mengandaikan keberanian bertindak tepat, meski menyadari penuh resiko. Tiga prinsip itu merupakan cara bagaimana mekanisme pembentukan habitus dipancing untuk bekerja. Hanya saja dalam pembentukan habitus selalu dikaitkan dengan kelas sosial atau lingkungan budaya/tradisi tertentu. Dalam konteks ini, habitus tidak bisa direduksi menjadi hasil dari teori behaviorisme. Maka salah satu pilar pembentukan karakter adalah displaying character, yaitu perwujudan karakter dalam praktek proses belajar-mengajar yang melibatkan semua pemangku kepentingan, baik secara individual (pendidikan, pejabat struktural, karyawan, mahasiswa, orang tua), maupun praktek lembaga (core values, kode etik dan peraturan-peraturan).

\section{Metode}

Dalam penulisan ini menggunakan metode konseptual analisis yang didukung data sekunder dan studi literatur. Pendekatan untuk menganalisis data berdasarkan perspektif kepentingan nasional, integratif serta analisisnya adalah multidisiplin sesuai dengan kerangka teoritis yang digunakan. Bahan-bahan yang dikumpulkan dengan metode tersebut dilihat secara komprehensif integral tentang internalisasi nilai-nilai Pancasila dalam mencegah perkembangan paham radikal. (Pudjiastuti; 2019).

\section{Hasil dan pembahasan}

a) Penghambat internalisasi nilai-nilai Pancasila.

Penghambat internalisasi nilai-nilai Pancasila; (1) lemahnya sistem pendidikan; temuan dalam penelitian yang dilakukan MAARIF Institut dalam beberapa hal bersifat menguatkan beberapa penelitian terdahulu mengenai adanya benih-benih radikalisme yang menyasar anak muda, utamanya pelajar SMA. Demikian juga dengan SETARA Institut yang pada Juni 2008 melakukan survei mengenai pandangan generasi muda terhadap persoalan kebangsaan, pluralitas dan kepemimpinan nasional (Setara Institut; 2008). Yang mana dalam survey tersebut, gejala fundamentalisasi agama pada generasi muda diukur melalui persetujuan pada hadirnya peraturan daerah berbasis agama, setidaknya 56,1\% menyetujuinya. Sementara 36,2\% menyatakan tidak.

Survei Lembaga Kajian Islam dan Perdamaian (LaKIP), dibawah pimpinan Bambang Pranowo pada Oktober 2010 hingga Januari 2011, menjelaskan 50\% siswa setuju tindakan radikal. Jumlah yang menyatakan setuju dengan kekerasan untuk solidaritas agama 52,3\% siswa dan 14,2\% membenarkan serangan bom (http://www.bbc.com; 3 Oktober 2017). Hal ini tentu menjadi perhatian semua pihak, terutama yang meyakini bahwa fundamentalisasi keagamaan adalah simtom awal bagi pandangan keagamaan yang dalam taraf tertentu menjadi pembenar bagi tindakan intoleran dengan menggunakan argumen keagamaan serta melanggar terhadap kebebasan beragama yang terkandung dalam nilai-nilai religiusitas pada sila pertama Pancasila.

Sikap anti nasionalisme juga pernah ditemukan di Kabupaten Karanganyar Jawa Tengah ada sekolah dan aparat sipil negara menyatakan tidak mau hormat pada sang saka merah putih dan lagu Indonesia Raya. Salah seorang murid SMP mengaku tidak tahu lagu Indonesia Raya, tidak hapal Pancasila, karena tak pernah diajarkan oleh guru di sekolahnya (Satriawan, 2011). Temuan berbagai lembaga riset ini telah menyadarkan kita bahwa krisis 


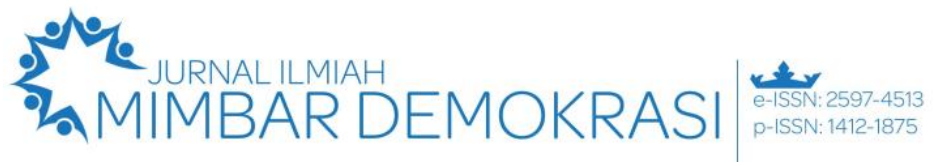

\section{Vol. 19 No. 2 Tahun 2020 | Hal. 32 - 39}

kebhinekaan yang termanifestasi melalui menguatnya fundamentalisasi di kalangan anak muda semakin memprihatinkan (Muhammad \& Pribadi, 2013). Kondisi seperti ini tidak bisa dibiarkan begitu saja ketika bangsa dan negara ini menaruh harapan yang tinggi dari generasi muda dalam kaitan dengan nasionalisme ke Indonesiaan sebagai negara bangsa.

(2) Resistensi terhadap ideologi Pancasila; Berbagai fenomena saat ini menunjukkan betapa nilai-nilai Pancasila mengalami erosi dan degradasi. Bahkan ketua fraksi PKB di MPR Lukman Edy menyatakan, ada sekitar 50 juta rakyat Indonesia anti Pancasila. Beliau mengatakan "paling tidak sekitar 50 juta rakyat Indonesia anti-Pancasila. Angka ini tentu mengejutkan tapi ini memang hasil dari survei secara acak dari berbagai institusi" (Fajar, 2011).

Hasil survei BPS menyebutkan 27\% rakyat Indonesia tidak perlu Pancasila. Bahkan penelitian seorang Profesor UIN menyatakan $28 \%$ setuju radikalisasi, dan lembaga kajian di Jakarta menyebutkan $10 \%$ pemuda Indonesia menginginkan syariat Islam menjadi dasar negara. Angka sebesar ini seharusnya dijadikan peringatan buat Indonesia, dan sekaligus seharusnya menjadi perhatian khusus dari pemerintah (Fajar, 2011). Tidak dapat di pungkiri kalau saat ini timbul pendiskriditan Pancasila, bahkan orang beranggapan tidak ada manfaatnya membicarakannya, sebab khawatir akan dianggap ingin menghidupkan kembali Orde Baru. Dari fenomena bidang politik, pimpinan politik masih terlihat mementingkan kompetisi mengenai jabatan dan kekuasaan sehingga tidak jarang yang menghalalkan segala cara untuk menang, tidak lagi menegakkan demokrasi yang sesuai dengan nilai-nilai Pancasila.

Resistensi generasi muda terhadap Ideologi Pancasila dapat dilihat dari penurunan internalisasi nilai-nilai tersebut. Hal ini dikarenakan nilai-nilai tersebut bagi beberapa komponen bangsa/generasi muda dianggap tidak populer dibandingkan nilai-nilai luar yang mereka anggap cocok untuk dijadikan nilai tertentu pada diri mereka. Bahkan pada beberapa hal, nilai-nilai Pancasila dianggap sebagai nilai yang identik dengan Orde Baru sehingga setiap hal yang berbunyi Pancasila akan dianggap sebagai bangkitnya Orde Baru. Saat ini pada kenyataannya penanaman nilai-nilai Pancasila hanya sebatas pada diajarkan/tidak ada dalam kurikulum pendidikan, namun tidak pada tataran dihayati apalagi diimplementasikan.

(3) Kurangnya keteladanan pemimpin; Pemimpin belum dapat bersikap seperti pamong dalam memberikan asah, asih, asuh kepada rakyat yang dipimpinnya, dan kemampuan seperti itu hanya bisa dicapai apabila pemimpin benar-benar mehami dan mengimplementasikan hakikat nilai-nilai luhur Pancasila dan dalam kehidupan sehari-hari. Korupsi yang terus mendera para elite politik dan penyelenggara dan penyelenggara negara, berkontribusi dalam menciptakan kemiskinan, pengangguran dan ketidak adilan sosial yang menjadikan semakin suburnya lahan radikalisme internasional berkembang. Radikalisme juga terpicu dengan adanya pandangan perlakuan tidak adil baik secara prosedural maupun distributif yang dilakukan oleh negara barat dibawah pimpinan Amerika Serikat dengan lembaga ekonomi dan politik nya yaitu; IMF, World Bank, dan WTP. Dari sisi ketidakadilan internasional PBB tidak adil karena lebih memihak negara-negara dibelahan bumi bagian utara yang menerapkan standar ganda dalam hubungan mereka dengan Israel dan sangat berbeda perlakuan mereka terhadap negara-negara yang berpenduduk mayoritas beragama Islam (Ancok, 2015).

(4) Pengaruh negatif meningkat; Globalisasi adalah sebuah proses integrasi internasional yang terjadi dikarenakan adanya pertukaran cara pandang, pemikiran, serta aspek budaya terhadap dunia. Globalisasi dapat dilakukan dengan melewati batas-batas negara sehingga globalisasi memiliki dampak negatif bangsa dan negara karena banyak masyarakat Indonesia sudah melupakan Pancasila, bahkan menyebut lima sila dalam Pancasila sudah tidak bisa, apalagi mengimplementasikan nilai-nilai yang terkandung di dalamnya (http://halra.com; 10 Agustus 2017). Pada perkembangan era teknologi saat ini, berbagai benturan, pergeseran, menggoyah nilai-nilai budaya bangsa berdasar Pancasila selalu terjadi. Pengaruh-pengaruh negatif tersebut banyak datang melalui media internet.

Dari sisi pengguna, angka mengejutkan terlihat dari hasil survei Asosiasi Penyelenggara Jasa Internet Indonesia (APJII) dan Lembaga Polling Indonesia (LPI) yang mengungkapkan bahwa angka pengguna internet Indonesia pada tahun 2016 telah mencapai angka 132,7 juta pengguna atau setara $51,7 \%$ dari populasi penduduk sebesar 256,2 juta jiwa. Angka 
tersebut melonjak dari tahun 2014 yang jumlahnya hanya 88,1 juta, angka ini masih akan terus bertambah mengingat ketersediaan perangkat, fasilitas, serta sarana prasarana penunjang internet yang masih terus menerus berkembang. Dari hasil lembaga riset internasional "We Are Social" menyebutkan bahwa Indonesia berada pada peringkat satu dunia dengan pertumbuhan 51\% dikategori Growth In Internet User melampaui Amerika, China serta negara lain di dunia (http://wearesocial.com; 2 Oktober 2017).

Angka penyalahgunaan internet masih saja terjadi. Maraknya berbagai kasus penipuan, pornografi dan pelecehan seksual, meningkatnya judi online dan transaksi narkoba melalui sosial media serta kasus kampanye hitam melalui internet juga turut menambah daftar dampak buruk internet yang mengundang perhatian banyak pihak. Pencurian akun sosial media, rekening bakn online dan virtual money juga sedang marak, selain itu kasus kejahatan didunia maya bahkan telah sampai pada pengrusakan dan pencurian portal atau situs penting milik pemerintah. Munculnya cyberbullying melalui jejaring sosial yang beredar dikalangan remaja dan anak-anak usia di bawah umur termasuk hal penting mengerikan sebab dapat mengganggu perkembangan psikologi dan kepribadian yang bersangkutan. Dari aspek sosial dan moral, dampak negatif yang paling mungkin akan terjadi adalah menurunnya kedalaman sosial, tergerusnya rasa kebersamaan dan gotong royong atau nilai kesetaraan pada sila ketiga Pancasila. Sifat-sifat masyarakat saat ini cenderung individualis dan dorongan untuk selalu ingin mendapatkan pujian orang lain dapat mengancam para pengguna internet mayoritas adalah remaja, generasi penerus bangsa.

\section{b) Implementasi internalisasi Pancasila}

Dalam tulisan ini, penulis memotret kondisi yang terjadi saat ini menggunakan nilai-nilai keyakinan intrinsik yang menjadi panduan dasar. Nilai-nilai keyakinan intrinsik ini merupakan sebuah national living road map yang mengantarkan bangsa Indonesia menjadi sebuah bangsa Pancasila, karena nilai-nilai keyakinan intrinsik tersebut menjadi jiwa dan nafas kehidupan dari kelima sila yang ada dalam Pancasila. Nilai-nilai keyakinan intrinsik ini adalah nilai religiusitas, nilai kekeluargaan, nilai keselarasan, nilai kerakyatan, dan nilai keadilan (Lemhanas, 2015). Jauh sebelum bangsa Indonesia memproklamasikan kemerdekaannya, kelima nilai keyakinan intrinsik ini sudah menjadi pandangan dasar kehidupan bermasyarakat Indonesia sehari-hari, sekaligus menjadi sebuah keyakinan dasar indeologis yang membedakannya dengan ideologi bangsa-bangsa lain di dunia. Kelima nilai dasar tersebut juga merupakan nilai-nilai keagungan dari keberadaan masyarakat negara bangsa Indonesia dalam setiap aspek kehidupan sosial yang mengantarkan terwujudnya masyarakat Indonesia yang adil dan makmur berlandaskan Pancasila dan UUD Negara Republik Indonesia 1945.

c) Nilai-nilai internalisasi Pancasila yang mampu menangkal paham radikalisme

Nilai-nilai internalisasi Pancasila yang diharapkan mampu menangkal paham radikalisme; (1) menguatnya sistem pendidikan, pendidikan merupakan salah satu komponen saja dari berbagai komponen bangsa. Pendidikan agama secara khusus, menjadi bagian dari pendidikan nasional yang diamanatkan dalam UU No.20 tahun 2003, dan karenanya di akui oleh negara, seperti disebutkan: jenis pendidikan mencakup pendidikan umum, kejuruan, akademik, profesi, vokasi, keagamaan, dan khusus. Pendidikan agama dirumuskan dalam PP No. 55 tahun 2007. Pendidikan memberi pengetahuan dan membentuk sikap, kepribadian, serta ketrampilan peserta didik dalam mengamalkan ajaran agamanya, yang diterapkan melalui mata pelajaran/kuliah pada semua jalur, jenjang, dan jenis pendidikan. Saat ini, pendidikan kewarganegaraan memainkan peran strategis dan penting dalam melestarikan, meningkatkan, dan mentransformasikan nilai-nilai ideologi dan nasionalisme negara kepada generasi muda (Bunyamin,2008). Model internalisasi pembelajaran nilai-nilai Pancasila dan mengimplementasikannya di sekolah dengan menggunakan berbagai model yang berbeda dalam setiap pembelajaran seperti model ceramah, diskusi, pemecahan masalah, jigsaw, audio visual, studi kasus dan permainan peran.(Wiratomo, Wahono, \& Kristiono, 2017)

(2) Penerimaan terhadap ideologi pancasila; temuan dalam pemetaan yang dilakukan MAARIF Institut dalam beberapa hal bersifat menguatkan beberapa penelitian terdahulu mengenai adanya benih-benih radikalisme yang menyasar anak muda, utamanya pelajar SMA. Sekedar menyebut pada tahun 2008, Farha Ciciek melakukan penelitian dalam konteks serupa. Demikian juga dengan SETARA Institut 


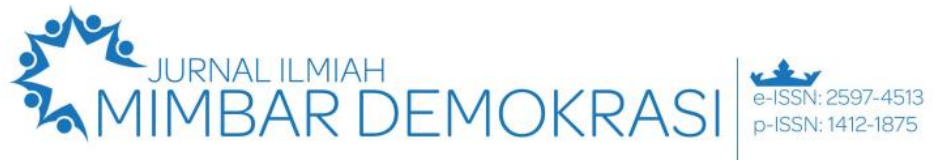

\section{Vol. 19 No. 2 Tahun 2020 | Hal. 32 - 39}

yang pada Juni 2008 melakukan survei mengenai pandangan generasi muda terhadap persoalan kebangsaan, pluralitas dan dan kepemimpinan nasional yang mana dalam survey tersebut, gejala fundamentalisasi agama pada generasi muda diukur melalui persetujuan pada hadirnya peraturan daerah berbasis agama, setidaknya $56,1 \%$ menyetujuinya. Sementara 36,2\% menyatakan tidak.

Hal ini tentu menjadi perhatian semua pihak terutama yang meyakini bahwa fundamentalisasi keagamaan adalah simtom awal bagi pandangan keagamaan yang dalam taraf tertentu menjadi pembenar bagi tindakan intoleran dengan menggunakan argumen keagamaan. Lebih lanjut fakta ini cukup mencengangkan manakala ditilik dengan kacamata konstitusi republik ini. Peraturan berbasis agama adalah kontradiksi yang nyata. Seperti dikutip dalam laporan SETARA Institut berikut; persetujuan kaum muda atas perdaperda syariah adalah bentuk kontradiksi demokrasi yang bertentangan dengan Pancasila dan UUD 1945. Jika Pancasila dan UUD 1945 diyakini menjadi dasar terbaik penyelenggaraan negara, kontradiksi-kontradiksi semacam ini, di mana terdapat kehendak melakukan totalisasi kebenaran di dalam wadah yang tunggal atas nama agama, seharusnya tidak muncul, karena Pancasila telah secara akomodatif mengakui keberagaman Indonesia. Fakta sosio-historis kebangsaan Indonesia adalah plural. Temuantemuan berbagai lembaga riset ini telah menyadarkan kita bahwa krisis kebhinekaan yang termanifestasi melalui menguatnya fundamentalisasi di kalangan anak muda semakin memprihatinkan (Muhammad \& Pribadi, 2013). Kondisi seperti ini tidak bisa dibiarkan begitu saja ketika bangsa dan negara ini menaruh harapan yang tinggi dari generasi muda dalam kaitan dengan nasionalisme ke Indonesiaan sebagai negara bangsa.

Globalisasi telah membawa perubahan bagi bangsa dan negara (Rosenau, 1990), yaitu perubahan negara yang terpusat pada negara kebangsaan, kepada dunia yang majemuk (Hall, 1990). Begitu juga yang dikatakan Kenichi Ohmae (1995) globalisasi dapat membawa kehancuran bagi negara dan bangsa. Presiden RI ke IV Susilo Bambang Yudoyono mengatakan bahwa diperkampungan global tetap diperlukan kehadiran rumah tangga negara kebangsaan. Begitu juga peringatan Bung Karno menyangkut nasionalisme Indonesia yang harus hidup dalam taman sarinya internasionalisme, sebaliknya hal tersebut tidak akan bisa hidup subur apabila tidak berakar dalam buminya nasionalisme. Oleh karena itu, generasi muda sebagai tulang punggung bangsa harus peduli dengan nasionalisme ke Indonesiaan.

(3) Keteladanan dari pemimpin; keteladanan merupakan salah satu modal dasar bagi masyarakat, bangsa dan negara. Dengan keteladanan yang dimiliki para pemimpin menjadi sarana untuk melakukan perubahan yang lebih baik. Yang menjadi modal pokok bangsa ini, tidak saja ekonomi dan politik, tapi keteladanan para tokoh bangsa ini. Dengan keteladanan, dapat dilakukan perubahan secara cepat dengan tidak menimbulkan dampak. Keteladanan menjadi dasar adanya perubahan. Keteladanan menjadi panglima utama, karena nya pemerintah haris dapat menjadi teladan. Keteladanan pemerintah terlihat dari berbagai hal, yaitu dari perilaku hidup sederhana. Aparatur negara dapat memiliki sikap sederhana dan tidak memamerkan kemewahan, hal ini salah satu wujud perilaku yang diharapkan sesuai dengan nilai-nilai yang terkandung dalam Pancasila dan dapat di terapkan pada kehidupan di masyarakat, bangsa dan negara sehingga para pemimpin nasional dapat dijadikan tauladan bagi masyarakat khususnya bagi generasi muda penerus bangsa.

(4) Pengaruh negatif dapat ditangkal; nilainilai Pancasila sebagai sumber moralitas dan etika bangsa Indonesia akan dapat diimplementasikan secara murni dan konsekwen oleh generasi muda apabila nilai-nilai yang tertera dalam dasar negara Pancasila dapat dan telah dipahami secara menyeluruh. Dengan memahami nilai-nilai luhur Pancasila dan UUD NRI Tahun 1945 sebagai satu kesatuan yang utuh, maka diharapkan dapat mengembangkan kesadaran generasi muda untuk mengamalkan nilai-nilai tersebut dalam pelaksanaan kehidupan sehari-hari.

Pemahaman yang mendalam yang kemudian secara konsisten diamalkan di dalam kehidupan sehari-hari akan dapat membangun kekuatan dalam berpikir, bersikap dan bertindak yang senantiasa mencerminkan pengejawantahan nilai-nilai Pancasila dan UUD Negara Republik Indonesia Tahun 1945. Melalui kondisi tersebut, nilai-nilai Pancasila dan UUD Begara Republik Indonesia Tahun 1945 yang telah menjadi budaya di dalam pelaksanan kehidupan praksis oleh generasi muda Indonesia tersebut, 
diharapkan dapat menjadi filter terhadap pengaruh budaya global sehingga budaya global yang positif dapat diadopsi dan sekaligus dapat memperkaya nilai-nilai praksis Pancasila, sedangkan budaya global negatif akan ditolak atau ditinggalkan. Dengan demikian, nilai-nilai Pancasila dan UUD Negara Republik Indonesia Tahun 1945 akan terus hidup di dalam pelaksanaan kehidupan bermasyarakat dan berbangsa, di mana semua itu juga merupakan cerminan dari budaya hukum masyarakat.

Upaya yang dilakukan untuk menginternalisasi nilai-nilai Pancasila dalam mencegah paham radikal adalah; (1) penguatan sistem pendidikan untuk mengoptimalkan internalisasi nilai Pancasila pada dunia pendidikan sehingga terwujud manusia berkualitas yang religius dan memiliki keyakinan adanya sang pencipta, berkualitas, berkarakter, menjadi warga negara yang demokratis, bertanggung jawab dan taat hukum melalui pendidikan, pelatihan, sosialisasi dan komunikasi sosial.

(2) Peningkatan jatidiri dan karakter bangsa berdasarkan Pancasila untuk menumbuhkembangkan sikap dan perilaku nasionalisme melalui perencanaan, revisi kebijakan, kerjasama, pembangunan dan sosialisasi. (3) Peningkatan komitmen pemimpin bangsa dalam mengaplikasikan nilai-nilai Pancasila untuk meningkatkan keteladanan bagi masyarakat melalui harmonisasi peraturan, sosialisasi, evaluasi, perencanaan dan penegakkan hukum. (4) Peningkatan pemahaman nilai-nilai Pancasila pada kehidupan sehari-hari untuk meningkatkan daya tangkal akan berpengaruh negatif melalui pendidikan, sosialisasi dan kerjasama.

\section{Simpulan}

Berdasarkan hasil analisis dan pembahasan berkaitan dengan internalisasi nilai-nilai Pancasila untuk mencegah perkembangan paham radikal dapat disimpulkan sebagai berikut; Nilai-nilai Pancasila belum teraktualisasi dengan baik sehingga belum dapat menangkal penyebaran paham radikal, tidak optimalnya pendidikan Pancasila, adanya penolakan terhadap ideologi Pancasila, kurangnya keteladanan dari pemimpin nasional, dan meningkatnya pengaruh negatif dari nilai-nilai luar yang tidak sesuai dengan Pancasila.

Strategi yang diterapkan adalah; penguatan sistem pendidikan untuk mengoptimalkan internalisasi nilai Pancasila pada dunia pendidikan sehingga terciptanya manusia yang berkualitas yang memiliki keimanan, keyakinan terhadap sang pencipta, berkualitas, berkarakter, menjadi warga negara yang demokratis, bertanggung jawab dan taat hukum melalui pendidikan, pelatihan, sosialisasi dan komunikasi sosial. Peningkatan jati diri dan karakter bangsa berdasarkan Pancasila untuk menumbuhkembangkan sikap dan perilaku nasionalisme melalui perencanaan, revisi kebijakan, kerjasama, pembangunan dan sosialisasi. Peningkatan komitmen para tokoh bangsa dalam mengaplikasikan nilai-nilai Pancasila untuk meningkatkan keteladan bagi masyarakat melalui harmonisasi peraturan, sosialisasi, evaluasi, perencanaan dan penegakkan hukum. Peningkatan pemahaman nilai-nilai Pancasila pada kehidupan sehari-hari untuk meningkatkan daya tangkal akan pengaruh negatif melalui pendidikan, sosialisasi dan kerjasama.

\section{Referensi}

Aini, Nur. (2017, 26 Juli). Survei BNPT: 39 Persen Mahasiswa Tertarik Paham Radikal. Republika.http://nasional.republika.co.id/ber ita/nasional/hukum/17/07/26/otonj7382survei-bnpt-39-persen-mahasiswa-tertarikpaham-radikal diunduh pada tanggal 3 Oktober 2017 pukul 16.00 WIB

Ancok, D (2015). Ketidakadilan sebagai sumber radikalisme dalam agama: Suatu Analisis berbasis teori keadilan dalam pendekatan psikologi. Jurnal Psikologi Indonesia.

BBC.com. (2017, 7 April). Bagaimana meredam paham radikal di Indonesia?. BBC.com News Indonesiahttp://www.bbc.com/indonesia/ind onesia-39494134 diakses pada 18 September 2017 pukul $17.00 \mathrm{WIB}$

Detik. (2015, 23 Februari). Mendagri: Tak Sesuai Pancasila, 100 Perda Bermasalah Dikembalikan. Detik.com http:/ / news.detik.com/berita/2840131/men dagri-tak-sesuai-pancasila-100-perda-

bermasalah-dikembalikan diakses 17 Juni 2017 pukul 18.20 WIB

Fajar, Danang. (2011, 25 Oktober). Survey BPS menyatakan 27 persen Rakyat Indonesia merasa tidak memerlukan Pancasila. 50 Juta Rakyat Indonesia Anti-Pancasila. Skala. https://skalanews.com/berita/nasional/umu $\mathrm{m} / 99246-50$-juta-rakyat-indonesia- 


\section{Vol. 19 No. 2 Tahun 2020 | Hal. 32 - 39}

antipancasila diakses pada tanggal 10 Agustus 2017

Giddens, A. (1989). Social theory of modern societies: Anthony Giddens and his critics. Cambridge University Press.

Hall, Edward T. \& Hall, Mildred R. (1990). Understanding Cultural Differences. Garden City, NY: Intercultural Press.Inc.

Hall, S. (1990). Globalization and ethnicity. In Anne McClintock, Aamir Mufti, \& Ella Shohat. (Eds), Dangerous Liaisons: Gender, Nation, and Postcolonial Perspectives. University of Minnesota Press.

Humannira, Raden Regia. (2016) Proses Internalisasi Nilai Kearifan Lokal Masyarakat Banten Pada Mahasiswa Yang Tergabung Dalam Organisasi Kedaerahan (studi deskriptif di organisasi kedaeraban Perbimpunan Mabasiswa Banten Bandung). Skripsi(S1), FKIP UNPAS.http://repository.unpas.ac.id/13175 /BAB\%202.pdf diunduh pada 18 September 2017

Kalidjernih, F. K. (2010). Kamus studi kewarganegaraan: perspektif sosiologikal dan politikal. Widya Aksara Press.

Lemhanas, Nilai-Nilai Kebangsaan yang Bersumber dari Pancasila, Jakarta; 2015.

Maftuh, Bunyamin. (2008). Internalisasi NilaiNilai Pancasila dan Nasionalisme Melalui Pendidikan Kewarganegaraan. Jurnal UPI.Kajian Filosofi,teori, kualitas dan manajemen pendidikan. Vil.II No.2 Juli 2008.

Muhammad, W. A., \& Pribadi, K. K. (2013). Anak muda, radikalisme, dan budaya populer. Jumal Maarif, 8(1), 132-53.

Napitupulu, Ester Lince. (2012, 31 Mei). Pengabaian Pendidikan Pancasila Berdampak Buruk.Kompas.com.

http:// nasional.kompas.com/read/212/05/31/1916552/Pengabaian.Pendidikan. Pancasila.Berdampak.Buruk diakses pada 18 September 2017 pukul 18.00 WIB

Ömae, K. I., \& Ohmae, K. (1995). The end of the nation state: The rise of regional economies. Simon and Schuster.

Pudjiastuti, Sri Rahayu,. (2019). Penelitian Pendidikan.Media Akademi.

Rosenau, J. N. (1990). Turbulence in world politics.

Rosenau, J. N. (1995). Governance in the twenty-first century. Global governance: A review of multilateralism and international organizations, 1(1), 13-43.

Satriawan, Yudha. (2011, 9 Juni). Anak Sekolah dan PNS di Karanganyar Tolak Hormat
Bendera.

$V O A$

Indonesia.

https://www.voaindonesia.com/a/pns-dananak-sekolah-tolak-hormat-bendera123578729/94215.html diakses pada tanggal 2 Oktober 2017 pukul 10.00 WIB

Scott, J. F. (1971). Internalization of norms. Englewood Cliffs, NJ, Prentice-Hall

Setara Institut. Berpibak dan Bertindak Intoleran (Laporan Kondisi Kebebasan Beragama/Berkeyakinan di Indonesia 2008), Jakarta; 2008.

Sindonews. (2016, 12 Mei). Sejarah Munculnya Radikalisme. Sindo.new. https://nasional.sindonews.com/read/11079 97/14/sejarah-munculnya-radikalisme1463048982 diaksespada tanggal 4 Oktober 2017 pukul $17.00 \mathrm{WIB}$

Sumardjoko, Bambang. (2017, 4 Desember). Aktualisasi Nilai-Nilai Pancasila Pada Masa Kini. Sindonews.com. https://nasional.sindonews.com/read/12103 72/18/aktualisasi-nilai-nilai-pancasila-padamasa-kini-1496431646 diakses pada 17 Juni 2017 pukul 18.05 WIB

Suparman, Mana. (2017, 11 Maret). Radikalisme Mengancam, Umur NKRI Diprediksi Tinggal 25 Tahun. Berita Satu. http://www.beritasatu.cpm/nasional/41876 2-radikalisme-mengancam-umur-nkridiprediksi-tinggal-25-tahun.html diakses pada 17 Juni 2017 pukul 17.30 WIB

Wijayaka, Bernadus. (2017, 7 Mei). Kepala BNPT: Penyebaran Paham Radikal di Kampus Sudah Mengkhawatirkan. Berita Satu. http://.beritasatu.com/hukum-kepalabnpt-penyebaran-paham-radikal-di-kampussudah-mengkhawatirkan.html diakses pada 17 Juni 2017 pukul 18.00 WIB

Wiratomo, G. H., Wahono, M., \& Kristiono, N. (2017). Model Internalisasi Nilai-Nilai Pancasila oleh Guru PPKn Jenjang SMP di Kota Semarang. Integralistik, 28(2), 119-130. 